\title{
Nowe wyzwania glottodydaktyki polonistycznej w Chińskiej Republice Ludowej
}

\author{
New challenges of teaching Polish as foreign language \\ in the People's Republic of China
}

\begin{abstract}
The article presents the current situation, challenges and problems of Polish studies in China. The oldest department of Polish studies in the PRC was established in 1954 at the Beijing Foreign Studies University and has been functioning to the present day. For over 50 years, there was only one department of Polish studies in the China mainland. However, since 2009, more Chinese universities have started to establish departments of Polish studies. As a result of the China - Central Eastern Europe Cooperation and the "One Belt, One Road" Initiative, the China - Poland relation has been developing dynamically in recent years. Today, in the academic year 2020/2021, 20 Chinese universities offer Polish language programs. The development brings excellent opportunities as well as great challenges for Polish studies in China. Teaching Polish as a foreign language in China, a country remarkably distant in language and culture from Poland, can pose not only entirely new problems but also open new possibilities for further research.
\end{abstract}

Keywords: Polish studies in China, teaching Polish as foreign language

\section{Wstęp}

Polonistyki na Dalekim Wschodzie mają już kilkudziesięcioletnią tradycję. Mimo odległości geograficznej dzielącej Polskę od krajów Dalekiego Wschodu i różnic systemowych pomiędzy językiem polskim a językami chińskim, koreańskim czy japońskim zainteresowanie studiami polskimi wykazały, choć 
w różnym czasie i z różnych powodów, zarówno Chiny, jak i Korea Południowa oraz Japonia.

Kilka lat po drugiej wojnie światowej Chińska Republika Ludowa i PRL nawiązały stosunki dyplomatyczne, dzięki czemu możliwe było utworzenie w 1954 roku pierwszej dalekowschodniej polonistyki w Pekinie. Pod koniec lat osiemdziesiątych ubiegłego wieku w Seulu w Korei Południowej rozpoczął swoją działalność Departament Studiów Polskich na Hankuk University of Foreign Studies (1987), a na początku lat dziewięćdziesiątych studia polskie utworzono na Tokyo University of Foreign Studies (1991) w stolicy Japonii. W 2007 roku z okazji dwudziestolecia istnienia Departamentu Studiów Polskich Koreańczycy zorganizowali międzynarodową konferencję pt. Studia polskie w Azji, na którą zaproszeni zostali poloniści chińscy i japońscy oraz naukowcy z Polski związani z tym wydziałem. Konferencja okazała się przełomowa dla studiów polskich na Dalekim Wschodzie. Zawiązana wówczas współpraca zaowocowała powstaniem Spotkań Polonistyk Trzech Krajów Chiny, Korea, Japonia (SPTK). Trudno zdecydowanie stwierdzić, czy jest to nazwa organizowanych co dwa lata konferencji, czy tomów pokonferencyjnych, zwanych rocznikami SPTK, czy też samej idei. Pierwsza konferencja pod szyldem SPTK została przygotowana przez polonistykę tokijską jesienią 2009 roku, druga odbyła się pół roku później w Pekinie, a następne już regularnie co dwa lata kolejno: w Seulu (2012), w Tokio (2014), w Kantonie (2016) i ponownie w Seulu (2018). SPTK planowane na jesień 2020 roku zostały przełożone w związku z pandemią COVID-19.

Kiedy polonistyki dalekowschodnie nawiązywały współpracę, nikt nie przewidywał zmian, do jakich miało dojść w ciągu następnych lat. Sytuacja polonistyki chińskiej jest obecnie wyjątkowa na tle polonistyk dalekowschodnich; w tej chwili powinna być rozpatrywana oddzielnie. Początkowo w każdym z trzech krajów azjatyckich funkcjonowała jedna polonistyka, w obrębie elitarnej jednostki na najlepszym uniwersytecie językowym w stolicy. W ciągu dziesięciu lat (2009-2019) na terenie Chińskiej Republiki Ludowej powstało dziewiętnaście (!) nowych ośrodków studiów polskich, z czego na piętnastu prowadzone są kierunkowe czteroletnie studia licencjackie w zakresie polonistyki (dodatkowo uczy się tam polskiego jako drugiego obowiązkowego języka) i cztery lektoraty'1.

Artykuł poświęcony jest tej wyjątkowej w skali światowej dynamice rozwoju studiów polskich w Chińskiej Republice Ludowej, genezie tego zjawiska oraz wyzwaniom i problemom, które z sobą niesie.

${ }^{1}$ Tam, gdzie prowadzone są studia czteroletnie, uczelnie oferują też zajęcia z polskiego dla studentów innych kierunków. Na czterech uczelniach w ofercie dydaktycznej są wyłącznie lektoraty języka polskiego jako drugiego/trzeciego (nie ma polonistyki). 


\section{Polonistyka chińska w latach 1954-2008}

Fakt, że wzrasta liczba rodowitych Chińczyków władających doskonale polszczyzną, znany jest $\mathrm{w}$ glottodydaktycznym polonistycznym środowisku akademickim w Polsce i na świecie. Chińscy poloniści uczestniczą w międzynarodowych konferencjach, przyjeżdżają na polskie uczelnie z cyklami wykładów lub jako profesorowie goszczą na parotygodniowych pobytach badaw$\mathrm{czych}^{2}$. Każdego roku przybywają do Polski liczne grupy chińskich stypendystów, i to nie tylko na kierunki prowadzone w języku angielskim (choć studiujących na nich też jest bardzo wielu), ale właśnie na filologię polską, na wszystkich poziomach kształcenia. Przyjeżdżający studenci mają za sobą minimum dwa lata intensywnej nauki języka polskiego w swoim kraju; w Polsce spędzają semestr lub dwa na jednym z polskich uniwersytetów. Prawie wszyscy studenci polonistyki w Chinach korzystają z możliwości odbycia stypendium w Polsce. Osobną grupę stanowią chińscy magistranci oraz doktoranci. Wyższą kadrę akademicką chińskich polonistów tworzą na razie absolwenci jednej uczelni — Pekińskiego Uniwersytetu Języków Obcych (PUJO) ${ }^{3}$ - do 2009 roku jedynej uczelni w Chińskiej Republice Ludowej, na której można było studiować język polski. Nadal jest to jedyna polonistyka, na której prowadzone są studia doktoranckie; do roku akademickiego 2019/2020 w Chinach tylko na PUJO oferowano studia magisterskie na kierunku polonistyka, od 2020/2021 studia drugiego stopnia na tym kierunku są również w ofercie Kantońskiego Uniwersytetu Spraw Międzynarodowych (Guangdong University of Foreign Studies).

Pierwsza polonistyka w Chinach powstała w 1954 roku. Dzięki nawiązaniu stosunków dyplomatycznych między naszymi krajami już na początku lat pięćdziesiątych XX wieku siedmioro studentów chińskich wyruszyło na kilkuletnie studia do Polski, także na polonistykę. W grupie tej był Xiao Huimin ${ }^{4}$, który po ukończeniu filologii polskiej na Wydziale Humanistycznym

${ }^{2}$ Chińscy poloniści gościli między innymi na Światowym Kongresie Polonistów zorganizowanym przez Uniwersytet Śląski w Katowicach w 2016 roku (Zhao Gang, Li Yinan, Mao Rui). Jako profesorowie wizytujący przebywali na Uniwersytecie Śląskim prof. dr Zhao Gang (w 2016 roku) oraz prof. dr Li Yinan (w 2017 roku) — prowadzili zajęcia na międzynarodowych studiach polskich oraz w Szkole Prawa i Kultury Chińskiej. Li Yinan jest pierwszą i do tej pory jedyną chińską polonistką z doktoratem uzyskanym w Polsce - na Uniwersytecie Śląskim obroniła rozprawę doktorską w języku polskim (Li Yinan: Recepcja literatury polskiej w Chinach. Wybrane zagadnienia. Praca doktorska. Uniwersytet Śląski w Katowicach. 2015. Pobrano z: https://rebus.us.edu.pl/bitstream/20.500.12128/5731/1/Li_Recepcja_literatury_polskiej_w_Chinach.pdf [2.09.2021]). Promotorem pracy był dr hab. Romuald Cudak, prof. UŚ.

${ }^{3}$ Polska nazwa tej uczelni oraz utworzony od niej skrótowiec są mocno utrwalone, dlatego będę ich używać w dalszej części artykułu.

${ }^{4} \mathrm{~W}$ artykule chińskie antroponimy zapisuję w szyku zgodnym z chińską normą językową. 
Uniwersytetu Warszawskiego wrócił do kraju i został pierwszym chińskim nauczycielem języka polskiego w Państwie Środka; wspomagał go lektor, Leszek Cyrzyk. Początkowo katedry języków polskiego i czeskiego funkcjonowały na Wydziale Rusycystyki na Uniwersytecie Pekińskim. W 1956 roku polonistykę i bohemistykę przeniesiono do Pekińskiego Instytutu Rusycystyki, gdzie utworzono samodzielny Wydział Języków Polskiego i Czeskiego. Pekiński Instytut Rusycystyki przekształcił się z czasem w Pekiński Instytut Języków Obcych, a w końcu w PUJO - Pekiński Uniwersytet Języków Obcych (Beijing Foreign Studies University) - i pod tą nazwą funkcjonuje do dziś. Wydział Języków Polskiego i Czeskiego stopniowo się rozrastał, powstawały kolejne katedry, aż wreszcie przemianowany został na Wydział Języków Wschodnioeuropejskich. Na początku XXI wieku zmieniono nazwę Wydziału na Wydział Języków Europejskich, a ostatecznie - Wydział Języków i Kultur Europejskich ${ }^{5}$ (ta nazwa obowiązuje do dziś). Od początku na polonistykę w PUJO naboru dokonywano raz na cztery lub raz na dwa lata. To znaczy, że przyjmowano jedną grupę studentów, która uczyła się razem od pierwszego roku do dyplomu. Dopiero gdy dana grupa skończyła studia, przyjmowano następną. Kilka razy w dziejach tego Instytutu dokonywano naboru, kiedy starsza grupa była na drugim roku. Jednocześnie w PUJO studiowało od dwudziestu (gdy uczył się jeden rocznik) do czterdziestu osób (kiedy studiowały dwa roczniki). Absolwenci tej uczelni stanowili grupę rodzimych użytkowników języka chińskiego władających polskim. W ciągu kilkudziesięciu lat wypromowano w sumie kilkaset osób. W tej chwili (rok 2021) jednocześnie kilkuset Chińczyków na kilkunastu uczelniach w całym kraju studiuje język polski na studiach licencjackich, magisterskich i doktoranckich lub uczy się go na lektoratach.

\section{Zmiany na rynku polonistycznym w Chinach po 2009 roku}

Od 2009 roku rozwój studiów polskich w Chinach nabrał niespotykanego nigdzie wcześniej rozmachu. Na początku 2021 roku na liście uczelni chińskich oferujących naukę języka polskiego jako obcego znalazło się dwadzieścia uniwersytetów (uczelnie uszeregowano chronologiczne, według dat ich powstania):

1. Pekiński Uniwersytet Języków Obcych / Beijing Foreign Studies University (1954).

2. Uniwersytet Pedagogiczny w Harbinie / Harbin Normal University (2009).

${ }^{5}$ Więcej na ten temat: Zhao Gang: 60 lat pekińskiej polonistyki. „Azja-Pacyfik” 2014, T. 17 , s. 103-113. https://doi.org/10.15804/ap201405. 
3. Północnowschodni Uniwersytet (Shenyang) / Northeastern University (2013).

4. Kantoński Uniwersytet Spraw Międzynarodowych / Guangdong University of Foreign Studies (2014).

5. Uniwersytet Spraw Międzynarodowych Hebei (Shijiazhuang) / Hebei Foreign Studies University (2014).

6. Pekiński Uniwersytet Studiów Międzynarodowych / Beijing International Studies University (2015).

7. Instytut Technologiczny Uniwersytetu Zhejiang w Ningbo / Zhejiang University Ningbo Institute of Technology (2016).

8. Instytut Chengdu, Syczuański Uniwersytet Studiów Międzynarodowych / Chengdu Institute, Sichuan International Studies University (2017).

9. Szanghajski Uniwersytet Studiów Międzynarodowych / Shanghai International Studies University (2017).

10. Uniwersytet Języków Obcych w Tianjinie / Tianjin Foreign Studies University (2017).

11. Uniwersytet Studiów Międzynarodowych w Xi'anie / Xi'an International Studies University (2017).

12. Uniwersytet Syczuański (Chengdu) / Sichuan University (2017).

13. Daliański Uniwersytet Języków Obcych / Dalian University of Foreign Languages (2018).

14. Uniwersytet Czangczuński / Changchun University (2018).

15. Pekiński Uniwersytet Sportowy / Beijing Sport University (2019).

16. Syczuański Uniwersytet Studiów Międzynarodowych (Chongqing) / Sichuan International Studies University (2019).

17. Uniwersytet Języków Obcych Zhejiang Yuexiu (Shaoxing) / Zhejiang Yuexiu University of Foreign Languages (2019).

18. Uniwersytet Studiów Międzynarodowych Jilin (Changchun) / Jilin International Studies University (2019).

19. Uniwersytet Studiów Międzynarodowych Zhejiang (Hangzhou) / Zhejiang International Studies University (2019).

20. Uniwersytet Zaozhuański / Zaozhuang University (2019).

Obecnie w ChRL funkcjonuje: piętnaście polonistyk, dwa ośrodki, w których nauka języka polskiego (jako drugiego języka obcego) jest obowiązkowa (Shijiazhuang, Chengdu), cztery lektoraty (Shenyang, Ningbo, Czangczun niezależnie od polonistyki, i Zaozhuang). W roku akademickim 2019/2020 języka polskiego na polonistykach (oraz na obowiązkowym lektoracie) uczyło się 740 studentów, dodatkowo w lektoratach wzięło udział ponad 170 osób ${ }^{6}$. Niemożność ustalenia dokładnej liczby studentów w roku akademickim 2020/2021 wynika z zakłóceń wywołanych pandemią. Część polonistyk nie zdecydowała

\footnotetext{
${ }^{6}$ Dane liczbowe uzyskano w Instytucie Polskim w Pekinie w lutym 2021 roku.
} 
się w tym roku na nabór, a aktualne dane z poszczególnych ośrodków nie spłynęły jeszcze do Instytutu Polskiego w Pekinie. Można założyć, że liczba studentów chińskiej polonistyki w roku akademickim 2020/2021 jest zbliżona do ich liczby w poprzednim roku. Nie wiadomo jeszcze, jaki wpływ na dalszy rozwój studiów polskich w Chinach będą miały konsekwencje pandemii COVID-19. W tej chwili trudno przewidzieć, jak w najbliższych latach będzie wyglądała polonistyka w Chinach, choć dotąd nic nie zwiastuje diametralnej zmiany sytuacji.

Co sprawiło, że w Chinach w ciągu dziecięciu lat (2009-2019) otwarto aż dziewiętnaście nowych ośrodków polonistycznych? W $2018 \mathrm{roku}^{7}$ odpowiedzi na to pytanie udzieliła Mao Rui, absolwentka PUJO, obecnie wykładowczyni na Szanghajskim Uniwersytecie Studiów Międzynarodowych. Pisała, że wzmożone działania Ambasady i konsulatów RP w Chinach oraz Instytutu Polskiego w Pekinie mogły mieć częściowy wpływ na zainteresowanie językiem polskim w tym kraju. Dodawała jednak:

nawet przy wielkim wysiłku ośrodków promujących Polskę, jej kulturę i język, w Chinach nie otwarto by tylu polonistyk, gdyby nie świadoma i pragmatyczna polityka rządu chińskiego, a zwłaszcza inicjatywa przypisywana przewodniczącemu Xi, Jeden Pas, Jeden Szlak (tzw. Nowy Jedwabny Szlak). Ta nagłośniona w ostatnich latach koncepcja stała się generatorem wzmożonych działań chińskich, w których uwagę poświęca się Europie Środkowo-Wschodniej, a szczególnie Polsce. [...] Bez wątpienia, podkreślmy to jeszcze raz, polski jest najbardziej promowanym językiem Europy Środkowo-Wschodniej w Chinach, na drugim miejscu znajduje się węgierski, a na trzecim - czeski ${ }^{8}$.

O znaczeniu inicjatywy Jeden Pas, Jeden Szlak dla rozwoju dydaktyki polonistycznej w Państwie Środka pisała wcześniej Li Yinan, szefowa Katedry Języka Polskiego na PUJO. Autorka podkreślała, że Chiny przywiązują coraz większą wagę do współpracy z Europą Środkowo-Wschodnią, co widać między innym w realizacji wspomnianej inicjatywy, a Polska stara się zdobyć przewodnią rolę we współpracy w ramach projektu $16+1^{9}$ i domaga się większego udziału w tym projekcie, który bazuje na inicjatywie Jeden Pas, Jeden Szlak. Li Yinan przywoływała ustanowiony w czerwcu 2016 roku doku-

7 W 2019 roku w Chinach powstało kolejnych sześć miejsc, w których oferowano naukę języka polskiego.

${ }^{8}$ Mao Rui: Chińscy studenci o rocznych stażach językowych w Polsce. „Kwartalnik Polonicum" 2018, nr 30, s. 57-58.

$916+1$ to nazwa projektu współpracy pomiędzy Chinami a szesnastoma państwami Europy Środkowej i Wschodniej (projekt stanowi inicjatywę chińskiego MSZ). 
ment o wszechstronnym partnerstwie strategicznym między naszymi krajami i związany z tym rozwój współpracy we wszystkich dziedzinach; dostrzegała w tym rozwoju współpracy znakomitą szansę, a jednocześnie wielkie wyzwanie dla wszystkich ośrodków polonistycznych w Chinach ${ }^{10}$.

Słowa Mao Rui i Li Yinan pozwalają wnioskować, że kolejne uniwersytety w tym kraju mogą wyrazić chęć otwarcia studiów polskich lub lektoratów języka polskiego, a liczba Chińczyków uczących się tego języka będzie nadal rosła. Nawet gdyby skutki pandemii były długofalowe, niełatwo będzie zapomnieć o tym, że w jednym kraju — w dodatku azjatyckim — w ciągu kilku lat liczba studentów w jednym czasie uczących się polskiego wzrosła z kilkudziesięciu osób do blisko tysiąca. Chęć odpowiedzi na zainteresowanie studentów studiami polskimi powoduje, że rośnie też grono wykładowców chińskich i lektorów języka polskiego (delegowanych z Polski). Wielu nauczycieli staje przed nowymi wyzwaniami. Należy odpowiedzieć na szereg pytań, między innymi: czego i jak uczyć?, jakie cele wyznaczać?, jak dostosować się do obecnej sytuacji rynkowej? Istniejąca przez ponad pięćdziesiąt lat na PUJO polonistyka, wówczas jedyna w Chinach, miała ściśle określone cele. Przede wszystkim kształciła tłumaczy do pracy w ambasadzie, ministerstwach, radiu, prasie i przedsiębiorstwach państwowych. Absolwenci polonistyki, którzy zdecydowali się na karierę akademicką, poświęcili się głównie tłumaczeniu literatury polskiej na język chiński ${ }^{11}$. Na chińskim rynku pracy już na przełomie wieków obserwowano wzrost zapotrzebowania na pracowników władających polskim. Również w Polsce można zaobserwować dynamiczny wzrost liczby instytucji zajmujących się nauczaniem języka chińskiego i promocją kultury chińskiej. Tłumacze polsko-chińscy potrzebni są w biznesie, turystyce, mediach, szkołach, na uczelniach, w bankach i instytucjach pozarządowych ${ }^{12}$. W związku $\mathrm{z}$ poszerzeniem spektrum branż, w których absolwenci chińskiej polonistyki znajdą zatrudnienie, konieczna jest też modyfikacja programów nauczania języka polskiego jako obcego.

W dalszej części artykułu przedstawię problemy, które wydają się wymagać najpilniejszych rozwiązań w tej niemającej precedensu sytuacji.

${ }^{10}$ Li Yinan: Dydaktyka polonistyczna wobec inicjatywy ,Jeden pas, jeden szlak”: programy i metody. „Spotkania Polonistyk Trzech Krajów — Chiny, Korea, Japonia” 2016/2017, s. 389.

${ }^{11}$ O tłumaczach i recepcji literatury polskiej w Chinach w monografii: Li Yinan: Literatura polska $w$ Chinach. Przedmowa Yi Lijun. Posłowie Zhao Gang. Uniwersytet Śląski-Wydawnictwo Gnome, Katowice 2017.

12 Por. Li Yinan: Dydaktyka polonistyczna wobec inicjatywy „Jeden pas, jeden szlak”..., s. 394. 


\section{Nauczyciele, wykładowcy, lektorzy - wyzwania, zadania, problemy}

Wraz ze wzrostem liczby studentów chińskich rośnie zapotrzebowanie na wykładowców. Jeśli chodzi o nauczycieli Chińczyków, popyt zdaje się większy niż podaż. Osoby, które ukończyły studia polskie przed okresem gwałtownego wzrostu liczby chińskich polonistyk lub w jego trakcie, nie są w stanie zaspokoić potrzeb całego rynku. Do tej pory tylko Pekin, Harbin i Kanton kształciły polonistów, którzy mogli podjąć pracę nauczycieli. Ci, którzy w ostatnich latach ukończyli polonistykę na innych uczelniach, muszą dodatkowo opanować metodykę nauczania języka polskiego jako obcego. Zwraca na to uwagę Mao Rui:

Kształcenie nowych kadr polonistów chińskich stało się obecnie prawdziwym wyzwaniem. Dlatego też wiele organizacji z Narodową Agencją Wymiany Akademickiej na czele ma świadomość, że powinny częściej odbywać się kursy doszkalające w zakresie metodyki nauczania języka polskiego jako obcego, by przyszłe kadry nie uczyły intuicyjnie, a co gorsza błędnie. Jako pierwszy potrzeby dokształcania młodych polonistów chińskich pod względem metodycznym zrozumiał PUJO, który we wrześniu 2017 roku zorganizował pierwsze ogólnochińskie warsztaty szkoleniowe. Zaproszeni polscy eksperci i doświadczeni chińscy poloniści przeprowadzili cykl wykładów oraz zajęć pokazowych, by zademonstrować swoim młodszym kolegom techniki i metody nauczania. Jest to niezwykle odpowiedzialne podejście do problemu, bo przecież chińscy filolodzy polscy nie mają w siatce godzin ani zajęć z metodyki, ani z pedagogiki, co jest pewnym błędem systemowym ${ }^{13}$.

Ten ,błąd systemowy” nie dotyczy wyłącznie chińskiego programu nauczania. W Polsce kształcenie lektorów języka polskiego jako obcego (jpjo) nabrało tempa w latach dziewięćdziesiątych ubiegłego wieku, kiedy to upowszechniły się letnie kursy języka polskiego, a od 1999/2000 na kolejnych uczelniach uruchamiano specjalistyczne studia podyplomowe, studia magisterskie i licencjackie w zakresie nauczania polskiego jako obcego i drugiego. „Obok studentów polskich interesowali się nimi [studiami w zakresie nauczania jpjo - J.M.] cudzoziemcy z krajów sąsiednich (np. Ukrainy, Białorusi, Rosji, Słowacji, Węgier), ale także z krajów odległych od Polski (np. z Tajwanu, Chin, Japonii)"14.

13 Mao Rui: Chińscy studenci o rocznych stażach językowych $w$ Polsce..., s. 60.

14 W.T. Miodunka et al.: Nauczanie i promocja języka polskiego $w$ świecie. Diagnoza, stan, perspektywy. Wydawnictwo Uniwersytetu Śląskiego, Katowice 2018, s. 179. 
Autorzy opracowania Nauczanie i promocja języka polskiego w świecie. Diagnoza, stan, perspektywy zwracają uwagę na niepokojący fakt: nauczycieli języka polskiego jako obcego i drugiego kształci się tylko w Polsce, a jedyny wyjątek w tym zakresie stanowi Uniwersytet w Lipsku. „Politykę językową w zakresie kształcenia nauczycieli polszczyzny jako języka obcego i drugiego realizują świadomie polskie uczelnie, a nie państwo polskie reprezentowane przez odpowiednie resorty"15.

Warto może dodać, że w Chinach praca na uczelni jest możliwa jedynie po ukończeniu studiów magisterskich, większość Chińczyków zaś po czteroletnich studiach pierwszego stopnia rozpoczyna poszukiwanie pracy. Ukończenie studiów magisterskich wymagałoby kolejnych dwóch i pół roku nauki, a pensja początkującego nauczyciela nie jest tak atrakcyjna jak pensja początkującego biznesmena. To może zniechęcać potencjalnych kandydatów na nauczycieli. W czasach, kiedy jedyna chińska polonistyka działała na PUJO, osoby decydujące się na karierę akademicką miały więcej czasu na dokształcanie się i podlegały znacznie mniejszej presji. Pod okiem swoich nauczycieli i przy wsparciu lektorów z Polski mogły spokojnie przygotować się do swojej roli. Obecnie przy tak dużym zapotrzebowaniu na nauczycieli języka polskiego konieczne jest podjęcie pracy w zawodzie właściwie tuż po studiach i niejednokrotnie w ośrodku znacznie oddalonym od macierzystej uczelni absolwenta i jego mistrzów. Większość nowych ośrodków rekrutuje chińskich lektorów języka polskiego spośród absolwentów polonistyki harbińskiej, natomiast starsze polonistyki zatrudniają przeważnie swoich absolwentów (choć niewyłącznie, na PUJO pracuje między innymi absolwent właśnie polonistyki harbińskiej). Lektorzy chińscy nie są zatrudniani w miejscach, gdzie w ofercie edukacyjnej jest jedynie lektorat języka polskiego lub gdzie studiuje tylko jeden rocznik. Sytuacja na chińskim rynku pracy nauczycieli języka polskiego jest jednak dosyć dynamiczna, co pokazuje lista dystrybucyjna Instytutu Polskiego w Pekinie, na której przybywa chińskich lektorów. Z rozmów przeprowadzanych przez Instytut Polski z przedstawicielami chińskich uczelni wynika, że tempo tworzenia w Chinach nowych ośrodków studiów polskich w ostatnich latach ujawniło brak wystarczającej liczby wykwalifikowanych lektorów języka polskiego, zarówno polskich, jak i chińskich. Można przypuszczać, że wraz z kończeniem studiów przez kolejne roczniki chińskich studentów polonistyki i rosnącą liczbą wracających do Chin absolwentów studiów magisterskich w Polsce niebawem poprawi się dostępność na rynku pracy chińskich lektorów języka polskiego ${ }^{16}$.

Młodzi nauczyciele języka polskiego, rodowici Chińczycy, mogą nie tyle nie poradzić sobie z czekającymi ich zadaniami dydaktycznymi, ile - jak

\footnotetext{
15 Ibidem, s. 183.

${ }^{16}$ Informacje uzyskane w Instytucie Polskim w Pekinie w lutym 2021.
} 
pisze Mao Rui - potrzebują wsparcia bardziej doświadczonych dydaktyków ${ }^{17}$. Aby precyzyjnie zdefiniować rodzaj i formę niezbędnego wsparcia, konieczne są szczegółowe badania oparte na monitorowaniu karier młodych chińskich nauczycieli, skupiające się na rozpoznaniu ich problemów w pracy dydaktycznej oraz sposobach radzenia sobie z nimi.

Także przed lektorami z Polski uczącymi języka polskiego w Chinach stoją spore wyzwania. Osoby, które chcą podjąć pracę na lektoracie zagranicznym, powinny ukończyć w Polsce specjalizację z nauczania języka polskiego jako obcego lub studia podyplomowe w tym zakresie, a przed wyjazdem zdać egzamin ministerialny ${ }^{18}$. Wymagania te dotyczą jednak tylko lektorów wysyłanych przez Narodową Agencję Wymiany Akademickiej (NAWA). Tymczasem tylko niespełna połowa ośrodków prowadzących studia polskie w Chinach ma podpisaną umowę z NAWA, w dodatku nie wszystkie te uczelnie utrzymują stały kontakt z Ambasadą RP w Pekinie, dlatego dane nie są do końca potwierdzone. Dodatkowo w roku akademickim 2020/2021 przepływ informacji, a więc uzyskanie rzetelnych danych o umowach między uczelniami i NAWA, był utrudniony obostrzeniami wynikającymi z trwania pandemii.

Wybuch pandemii w Chinach w 2020 roku zbiegł się z najważniejszymi chińskimi świętami, w tym Chińskim Nowym Rokiem, kiedy to szkoły i uczelnie wyższe mają kilkutygodniowe ferie. Większość przebywających w Chinach cudzoziemskich nauczycieli wykorzystała te długie wakacje na wyjazd do swojego kraju lub podróże. Początkowo władze uczelni odradzały swoim pracownikom powrót do Chin, później stał się on niemożliwy, ponieważ na całym świecie wprowadzono ograniczenia w podróżowaniu. Niektórzy z lektorów próbowali przeczekać trudności, uczyli zdalnie i tak samo przedłużali swoje kontrakty, wielu jednak zrezygnowało (nie tylko Polacy). W związku z tym stan obecny (początek 2021 roku) na rynku lektorów języka polskiego możemy zrekonstruować tylko na podstawie danych z Ambasady RP w Chinach i list lektoratów udostępnianych przez NAWA; trudno udokumentować, jak wielu lektorów polskiego pracuje na uczelniach, które nie mają podpisanej umowy z NAWA. Według dostępnych informacji w lutym 2021 roku ogłoszo-

17 Takim wsparciem dla początkujących nauczycieli mają być zajęcia w ramach Ogólnochińskich Warsztatów Glottodydaktycznych; to wydarzenie o charakterze cyklicznym w 2020 roku odbyło się online.

${ }^{18}$ Więcej o ogólnej sytuacji lektorów języka polskiego na uczelniach zagranicznych — oczekiwaniu ośrodków zagranicznych wobec lektorów, realizacji zobowiązań — w: W.T. Miodunka et al.: Nauczanie i promocja języka polskiego w świecie..., s. 186-203; J. Mazur: Lektor języka polskiego w zagranicznym ośrodku akademickim. Oczekiwania i rzeczywistość. W: W kręgu (glotto)dydaktyki. Red. A. Achtelik, K. Graboń. [Polonistyka na początku XXI wieku. Diagnozy, koncepcje, perspektywy. Red. J. Tambor. T. 5]. Wydawnictwo Uniwersytetu Śląskiego, Katowice 2018 , s. $55-62$. 
no nabór lektorów NAWA do ośmiu chińskich ośrodków: PUJO i Beijing International Studies University (w Pekinie), Shanghai International Studies University, Guangdong University of Foreign Studies (w Kantonie), Tianjin Foreign Studies University, Dalian University of Foreign Languages, Harbin Normal University, Northeastern University (w Shenyangu). W pozostałych ośrodkach lektorzy z Polski zatrudniani są na różnych zasadach — na podstawie umowy $\mathrm{z}$ uczelnią partnerską w Polsce lub indywidualnie przeprowadzonego naboru ${ }^{19}$. Do Ambasady regularnie napływają informacje o poszukiwaniu polskich lektorów przez uczelnie. W ostatnich latach większość studiów polskich powstała bez nawiązania współpracy z NAWA.

Ze względu na dynamikę rozwoju studiów polskich w Chinach trudno opracować dokładny, jednolity i aktualny raport na ten temat. Stworzenie takiego opisu wydaje się jednak absolutną koniecznością. Dlatego w bieżącym roku zaplanowano - z inicjatywy lektorów języka polskiego, zarówno rodowitych Chińczyków, jak i obcokrajowców, o najdłuższym stażu pracy w Chinach zebranie szczegółowych informacji dotyczących wszystkich polonistyk i lektoratów w Państwie Środka, ponadto podsumowanie Ogólnochińskich Warsztatów Glottodydaktycznych z okazji ich piątej edycji (liczonej od warsztatów „zerowych”) i wydanie tych materiałów w formie książkowej.

Przed polskimi lektorami przyjeżdżającymi do Chin stoją różne wyzwania. Muszą oni poradzić sobie nie tylko z formalnościami, lecz także z problemami, z którymi spotykają się wszyscy w tym zawodzie (por. przypis 14); dodatkowo mierzą się z nowym doświadczeniem - nauczania w warunkach chińskich oraz ogólnie pojętym szokiem kulturowym, o którym tak pisze Urszula Żydek-Bednarczuk:

Szok kulturowy wiąże się z dłuższym przebywaniem w obcej kulturze, jest reakcją na zmianę otoczenia, wiąże się z „brakiem lub zniekształceniem wielu bodźców, z którymi spotykamy się we własnym kraju, i zastąpieniem ich innymi, obcymi nam bodźcami”. W przeciwieństwie do incydentu krytycznego, szok kulturowy jest zjawiskiem rozłożonym w czasie. Wskutek szoku kulturowego ludzie wykształcają dwa typy postaw:

1. Idealizacja kultury rodzimej i ostre przeciwstawienie się nowemu środowisku — postawa bliższa cywilizacji zachodniej.

2. Porzucenie kultury rodzimej na rzecz nowej kultury — postawa charakterystyczna dla kultur prymitywnych ${ }^{20}$.

${ }_{19}$ Niestety brak jakichkolwiek danych za rok akademicki 2021/2022.

${ }^{20}$ U. Żydek-Bednarczuk: Spotkanie kultur. Komunikacja i edukacja międzykulturowa $w$ glottodydaktyce. Wydawnictwo Uniwersytetu Śląskiego, Katowice 2015, s. 33-34 (autorka cytuje fragment z: E.T. Hall: Bezgłośny język. Tłum. R. Zimand, A. Skarbińska. Warszawa 1987, s. 171). 
Stanowisk lektorskich w Chinach nie obejmują na razie polscy sinolodzy, choć byłoby to możliwe po ukończeniu przez nich studiów podyplomowych z nauczania jpjo. Oczywiście, nie jest powiedziane, że polski sinolog nie byłby narażony na szok kulturowy, ale można założyć, że w jakimś stopniu zna już miejscowe zwyczaje i być może nawet przebywał w tym kraju na studiach. Niektórzy polscy lektorzy znają chiński - uczyli się go wcześniej lub podjęli trud jego nauki już na miejscu — bez wątpienia jednak każdy z nich spotyka się z rzeczywistością skrajnie odmienną od tej, do której przywykł. Nawet osoby $\mathrm{z}$ dużym doświadczeniem $\mathrm{w}$ nauczaniu jpjo w Polsce lub kraju $\mathrm{z}$ europejskim dziedzictwem kulturowym mogą mieć problemy z przystosowaniem się do miejscowych, chińskich realiów, dla niektórych osób różnice kulturowe do końca pozostaną nie do zaakceptowania ${ }^{21}$. W Polsce i Chinach odmienny jest system edukacji i organizacja życia akademickiego, największa trudność związana jest jednak ze specyfiką nauczania języka o strukturze całkowicie odmiennej od struktury języka chińskiego i wprowadzania obcych Chińczykom treści kulturowych. Nauczanie w tak odległym kraju, znajdującym się w innym kręgu kulturowym, wiąże się z koniecznością ciągłego przekraczania barier i nieustannego poszukiwania kompromisu. Różnice kulturowe widoczne są w prawie każdej sferze życia - inne są zwyczaje i normy kulturowe dotyczące jedzenia, ubioru, gestykulacji i mimiki, sposobów spędzania wolnego czasu, obchodzenia świąt i uroczystości, relacji rodzinnych, relacji w miejscu pracy i ogólnie w życiu społecznym, grzeczności językowej i kultury osobistej²2.

Prawdą jest, że lektorzy, którzy przybywają do Chin bez wcześniejszego przygotowania kulturowego, napotykają na swojej drodze przeszkody, których nie potrafią pokonać lub działając po omacku, zdobywają doświadczenie, ucząc się na własnych błędach ${ }^{23}$.

Niezwykle ważną inicjatywą służącą wspieraniu lektorów języka polskiego (zarówno rodowitych Chińczyków, jak i Polaków) w Chinach są wspomniane Ogólnochińskie Warsztaty Glottodydaktyczne organizowane od 2018 roku przez Ambasadę RP i Instytut Polski w Pekinie ${ }^{24}$. Genezę Warsztatów, ich cele

${ }^{21}$ Por. J. Malejka: Na głęboka wode, czyli o zaletach ( $i$ wadach) komunikowania się z Chińczykami wyłacznie po polsku. „Spotkania Polonistyk Trzech Krajów - Chiny, Korea, Japonia” 2009, s. $167-177$.

${ }^{22}$ Więcej na ten temat w artykule: J. Malejka: Podejście międzykulturowe w nauczaniu języka polskiego w Chinach [w druku].

${ }^{23}$ A. Ruszer: Ogólnochińskie Warsztaty Glottodydaktyczne w Pekinie i promocja języka polskiego w Chinach. [W przygotowaniu]. Dziękuję Panu dr. Andrzejowi Ruszerowi za udostępnienie tekstu w jego wersji przed opublikowaniem.

${ }^{24}$ Wcześniej, we wrześniu 2017 roku, odbyły się warsztaty zorganizowane z inicjatywy polonistyki pekińskiej (Centrum Studiów Polskich i Katedrę Języka Polskiego PUJO). Wykłady goś- 
i założenia szczegółowo opisuje Andrzej Ruszer w artykule Ogólnochińskie Warsztaty Glottodydaktyczne w Pekinie i promocja języka polskiego w Chi$n a c h^{25}$. Inspirację do stworzenia tego wydarzenia autor dostrzega w Spotkaniach Polonistyk Trzech Krajów:

Ta międzynarodowa konferencja skłoniła wielu polonistów uczących w Chinach do wyjścia z inicjatywą powołania „wewnętrznych” warsztatów obejmujących wszystkie polonistyki i lektoraty języka polskiego istniejące w Państwie Środka. Decyzja o powołaniu spotkań na terenie Chin była na tyle zasadna, że udział w SPTK ograniczony był do kręgu wybranych polonistyk chińskich - pekińskiej (od samego początku do 2007 roku), harbińskiej, kantońskiej, lektoratu w Zhaoqingu (od 2014 roku), szanghajskiej oraz lektoratu w Shenyangu (od 2018 roku). Pozostałe nowo powstałe polonistyki i lektoraty języka polskiego, których nagle pojawiło się w Chinach tak wiele, nie miały szans na udział w nieco już „familijnej” i „konserwatywnej” wspólnocie SPTK. Zresztą zadecydowały o tym względy czysto logistyczne, bo Chiny, mające ogromną przewagę ilościową nad swoimi partnerami w Korei i Japonii, nie chciały forsować udziału nowych członków z punktu widzenia taktyki dyplomatycznej. Oznaczało to, że nie chciały być odbierane jako hegemon glottodydaktyczny w Azji. Ta, skądinąd słuszna, decyzja zrodziła potrzebę powołania innych spotkań, których odbiorcami byliby przede wszystkim pracujący w Chinach lektorzy i polonistyczna kadra naukowo-dydaktyczna ${ }^{26}$.

Cele Ogólnochińskich Warsztatów Glottodydaktycznych to integracja środowiska polonistycznego, wymiana doświadczeń i dobrych praktyk oraz prezentacja nowych osiągnięć czy powstających podręczników i pomocy dydaktycznych. Jak pisze Ruszer: ,jednym z najważniejszych punktów programu warsztatów są spotkania z niekwestionowanymi autorytetami polskiej sceny glottodydaktycznej"'27.

Okoliczności wywołane pandemią spowodowały, że Warsztaty w 2020 roku odbyły się $\mathrm{w}$ formie zdalnej. $\mathrm{Z}$ uwagi na duże ograniczenia w poruszaniu się na terenie Chin zebranie się zainteresowanych było utrudnione, ponadto

cinne wygłosiły prof. dr hab. Jolanta Tambor i dr Agnieszka Tambor z Uniwersytetu Śląskiego w Katowicach, a zajęcia praktyczne i lekcje pokazowe przeprowadzili wykładowcy PUJO. Andrzej Ruszer pisze, że ta pierwsza udana próba zainspirowała organizatorów do rozszerzenia formuły. W 2018 roku organizację warsztatów przejęły Ambasada RP w Pekinie i Instytut Polski w Pekinie. Ibidem.

${ }^{25}$ Ibidem.

${ }^{26}$ Ibidem.

${ }^{27}$ Ibidem. 
większość lektorów z Polski nie zdołała wrócić do pracy po feriach zimowych, wykluczony był też udział gości z Polski ${ }^{28}$. Materiały z poprzednich, II Ogólnochińskich Warsztatów Językowych zostały opublikowane wspólnie przez Ambasadę RP, Instytut Polski w Pekinie i Centrum Studiów Polskich PUJO. W publikacji znalazły się teksty wystąpień uczestników, przykładowe konspekty lekcji języka polskiego oraz wykaz polonistyk i lektoratów w ChRL ${ }^{29}$. Jak już wspomniano, planowane jest wydanie obszerniejszej publikacji podsumowującej dorobek Warsztatów oraz aktualny stan chińskiej polonistyki.

\section{Nauczanie języka polskiego jako obcego}

\section{Cele i programy nauczania}

Wszyscy studenci polonistyk w Państwie Środka to rodowici Chińczycy, którzy rozpoczynają naukę od poziomu zerowego. Studia pierwszego stopnia trwają cztery lata. Tylko nieliczni absolwenci podejmują studia magisterskie, które nie tylko nie są wymagane na rynku pracy, ale wręcz opóźniają rozpoczęcie pracy. Dlatego na studia magisterskie decydują się głównie osoby zainteresowane karierą akademicką.

Po czterech latach nauki absolwenci studiów pierwszego stopnia powinni osiągnąć poziom językowy B2/C1. W ostatnich latach coraz więcej osób zainteresowanych jest przystąpieniem do egzaminu certyfikatowego i poświadczeniem znajomości języka polskiego jako obcego jeszcze przed ukończeniem studiów. Bardzo dużym ułatwieniem w tej kwestii jest organizowanie egzaminu certyfikatowego na terenie ChRL (od 2007 roku) ${ }^{30}$; wielu studentów przystępuje też do egzaminu certyfikatowego podczas studiów semestralnych i rocznych w Polsce.

${ }^{28}$ Dokładny opis przebiegu III Warsztatów znajduje się w cytowanym artykule Andrzeja Ruszera (ibidem).

${ }^{29}$ II Ogólnochińskie Warsztaty Glottodydaktyczne. Pekin, 7-9 kwietnia 2019 r. [Materiały powarsztatowe]. Ambasada RP w Pekinie, Pekin 2019.

${ }^{30}$ Mimo ogromnego zainteresowania w roku akademickim 2020/2021 egzamin certyfikatowy poświadczający znajomość języka polskiego nie mógł się odbyć. Członkami państwowej komisji przeprowadzającej egzaminy w Pekinie były do tej pory osoby spoza Chin, które przyjeżdżały na egzamin; od kilku lat w skład komisji mogą wchodzić uprawnieni lektorzy języka polskiego pracujący w Chinach. W roku akademickim 2020/2021 nie było jednak na terenie Chin osoby posiadającej uprawnienia przewodniczącego, a z powodu pandemii nie mógł przyjechać nikt z zewnatrz. 
Jak pisze Li Yinan w przywołanym wcześniej artykule, treści edukacyjne muszą być dostosowane do aktualnych potrzeb rynkowych ${ }^{31}$. Niewielki procent studentów polonistyki jest obecnie zainteresowany studiami historyczno- czy teoretycznoliterackimi. Większość absolwentów polonistyki chińskiej będzie szukać pracy w handlu, biznesie, turystyce, bankowości, mediach, instytucjach kulturalnych itp. Poszczególne ośrodki starają się stworzyć ofertę dydaktyczną odpowiadającą na potrzeby rynku pracy. Zdaniem Li Yinan

stajemy wobec ważnego wyzwania: jaką kadrę powinniśmy kształcić? W jaki sposób możemy realizować swój cel? [...] Na PUJO prowadzimy studia polonistyczne, podczas których studenci nie tylko zdobywają podstawową znajomość języka, ale także wszechstronną wiedzę o Polsce i różnorodne umiejętności praktyczne. O charakterze takich studiów decyduje zarówno potrzeba rynkowa i tradycja dydaktyczna, jak i strategia państwowa ${ }^{32}$.

Autorka zaznacza, że spójny system nauczania języka i kultury polskiej funkcjonujący na PUJO został wypracowany przez kilka pokoleń wykładowców. Nie ulega wątpliwości, że większość nowych polonistyk musiała z tych wzorców czerpać, zwłaszcza że kadra tworząca nowe miejsca wywodziła się właśnie z absolwentów PUJO. Na polonistykach nowszych i najnowszych, które powstały w ostatnich dwóch latach, system nauczania języka i kultury polskiej może być inny, ale trudno to stwierdzić w tym momencie, ponieważ zgromadzone dane nie są jeszcze kompletne. Ze względu na pewne lokalne uwarunkowania programy nauczania realizowane na poszczególnych uczelniach nie są powszechnie dostępne.

W swoim artykule Li Yinan szczegółowo opisuje program studiów pierwszego stopnia polonistyki opracowany w 2016 roku na PUJO $^{33}$. Podobne treści nauczania, zorganizowane w podobny sposób, są realizowane między innymi na polonistykach w Szanghaju i Kantonie. Przedmioty na tych polonistykach można podzielić na trzy główne bloki: zajęcia językowe, wiedza o Polsce i przedmioty kierunkowe.

Zajęcia językowe mają na celu kształcenie poszczególnych sprawności: słuchania, mówienia, czytania, pisania (w tym poprawności gramatycznej); przedmioty te są realizowane $\mathrm{w}$ różnych modułach $\mathrm{w}$ zależności od poziomu zaawansowania. Na przykład gramatyka początkowo jest wykładana przez wykładowców chińskich, którzy w rodzimym języku studentów tłumaczą im zupełnie odmienny system językowy. Na zajęciach lektoratowych studenci

\footnotetext{
${ }^{31}$ Li Yinan: Dydaktyka polonistyczna wobec inicjatywy „Jeden pas, jeden szlak”..., s. 394.

32 Ibidem, s. 389.

33 Opis studiów polonistycznych na PUJO podaję za: ibidem, s. 390-395.
} 
uczą się gramatyki, ale równolegle poznają teorię stanowiącą wprowadzenie do systemu języka polskiego. Wraz z rozwojem kompetencji językowych studentów do ich programu nauczania dochodzą inne przedmioty, na przykład dyskusje i wystąpienia w języku polskim, pisanie oficjalnych dokumentów w języku polskim, pisanie tekstów akademickich, chińsko-polskie tłumaczenie ustne i pisemne.

Na początku studiów odbywa się kurs w języku chińskim: wprowadzenie do wiedzy o Polsce; w kolejnych semestrach dochodzą przedmioty wykładane już w języku polskim: historia literatury i kultury polskiej oraz historia Polski. PUJO oferuje także zajęcia, na których omawiane są wybrane problemy polskiej polityki oraz wybrane problemy polskiej ekonomii i handlu, a na czwartym roku po polsku przedmiot: kultura Chin; Kantoński Uniwersytet Spraw Międzynarodowych oferuje studentom przedmioty język polski w biznesie i język polski w turystyce.

Na polonistyce w PUJO odbywają się też dodatkowe zajęcia z przedmiotów specjalistycznych, dzięki czemu studenci mogą wybierać zajęcia zgodnie ze swoimi zainteresowaniami i dalszymi planami zawodowymi; do wyboru są cztery kierunki: społeczeństwo polskie, literatura i sztuka polska, tłumaczenie chińsko-polskie oraz media. Kierunek społeczeństwo polskie obejmuje następujące przedmioty: systemy i partie polityczne Polski, polityka zagraniczna Polski, ekonomia, handel i inwestycje w Polsce, Polska w XX wieku, polskie dziedzictwo naturalne i kulturowe, stosunki polsko-chińskie, historia i status Unii Europejskiej; kierunek literatura i sztuka polska: wybrane dzieła polskiej literatury klasycznej, polska kultura i sztuka współczesna, zwyczaje i świat duchowy Polaków, polsko-chińska wymiana literacka, film polski; tłumaczenie chińsko-polskie: teoria i praktyka, tłumaczenie tekstów prawnych, tłumaczenie literackie, tłumaczenie ustne poziom zaawansowany; media: obraz Chin w polskich mediach, polskie radio i telewizja, polskie nowe media, pisanie artykułów prasowych w języku polskim ${ }^{34}$.

Polonistyki w Szanghaju i Kantonie starają się oferować podobnie atrakcyjny program nauczania, ale ze względu na ograniczone zasoby kadrowe nie mają na razie takich możliwości; dotyczy to głównie przedmiotów specjalistycznych. Nauczanie języka i wiedzy o Polsce realizowane jest na tych uczelniach $\mathrm{w}$ ramach podobnych przedmiotów i zbliżonego wymiaru godzin. Można przypuszczać, że na pozostałych chińskich polonistykach są lub wkrótce będą realizowane podobne programy nauczania.

\footnotetext{
34 Ibidem.
} 


\section{Podręczniki i materiały edukacyjne}

Przez wiele lat na polonistyce pekińskiej korzystano z podręcznika do nauki języka polskiego dla Chińczyków autorstwa Li Jintao oraz podręcznika do gramatyki tego samego autora. Podręczniki były podstawą kształcenia wielu chińskich polonistów i nie można umniejszać wagi tych publikacji, w pewnym momencie - wraz z postępem wiedzy glottodydaktycznej — stały się jednak niewystarczające, zwłaszcza dla przyjeżdżających do Chin lektorów, szkolonych według zasad współczesnej glottodydaktyki polonistycznej. Zaczęto uczyć z powszechnie dostępnych uniwersalnych podręczników (autorstwa Polaków), jak te z serii Hurra!!! oraz podręcznik Polski krok po kroku ${ }^{35}$. Nie jest to rozwiązanie idealne, ponieważ po pierwsze, w podręcznikach brakuje informacji dodatkowych w języku chińskim, które są pomocne zwłaszcza dla studentów początkujących, po drugie, treści uniwersalne to tak naprawdę treści zachodniego kręgu kulturowego, a to oznacza, że studenci chińscy (a także Japończycy i Koreańczycy) nie znajdują w tych książkach odniesień do swojego świata. Jolanta Tambor pisze:

Jednym z przykładów dostrzegania potrzeby takiego podejścia w glottodydaktyce, czyli nazywania obcych realiów w języku polskim, są podręczniki do języka polskiego dla Japończyków i Chińczyków — po erze zachłyśnięcia się podręcznikami uniwersalnymi, dla wszystkich, bez pośrednictwa języka-medium, zaczynamy wracać do idei podręczników „dedykowanych”, kierowanych, adresowanych do konkretnych grup narodowych i językowych ${ }^{36}$.

Konieczność stworzenia nowych podręczników do nauki języka i kultury polskiej dostrzegły także polonistyki chińskie. Na PUJO powstaje — we współpracy z Uniwersytetem Śląskim - podręcznik dla początkujących Ni hao, Polsko autorstwa Li Yinan, Mao Rui, Mao Yinhui, Anny Gałęziowskiej-Krzystolik, Barbary Morcinek-Abramczyk i Agnieszki Tambor oraz podręcznik do nauczania literatury polskiej dla zaawansowanych Andrzeja Ruszera; na Szanghajskim Uniwersytecie Studiów Międzynarodowych — podręcznik

${ }^{35}$ L. Madelska, M. Warchoł-Schlottmann: Odkrywamy język polski. Gramatyka dla uczacych (się) języka polskiego jako obcego. Wyd. 2. [Hura!!!]. Prolog Publishing, Kraków 2018; M. Małolepsza, A. Szymkiewicz: Po polsku 1. Podręcznik studenta. Wyd. 2. popr. [Hura!!!]. Prolog Szkoła Języków Obcych, Kraków 2006; W. Miodunka, J. Wróbel: Polska po polsku. Podręcznik języka polskiego dla poczatkujacych. T. 1. Interpress, Warszawa 1986; I. Stempek, A. Stelmach: Polski krok po kroku. Seria podręczników do nauki języka polskiego dla obcokrajowców. Poziom A2. Polish-courses.com, Kraków 2012.

36 J. Tambor: Egzotyzmy kulinarne w i na języku Polaków. Rozważania o jedzeniu, mówieniu i pisaniu. „Spotkania Polonistyk Trzech Krajów - Chiny, Korea, Japonia” 2014/2015, s. 84 - 85. 
do historii Polski Tomasza Ewertowskiego i Mao Rui, podręcznik do tłumaczeń ustnych Mao Rui oraz nowa praktyczna gramatyka języka polskiego dla Chińczyków Mao Rui i Jagny Malejki. Na Kantońskim Uniwersytecie Spraw Międzynarodowych pod kierunkiem Mao Yinhui powstaje podręcznik dla początkujących oraz dla średniozaawansowanych Turystyczny język polski. Proces powstawania podręczników w warunkach chińskich jest długi, więc na zapowiadane pozycje trzeba będzie jeszcze poczekać. Ważne, że dostrzeżono potrzeby chińskiego rynku polonistycznego i podejmuje się próby odpowiedzi na nie nowoczesnymi podręcznikami przeznaczonymi dla rodzimych odbiorców.

Autorzy nowoczesnych podręczników przeznaczonych dla chińskich studentów polonistyki spotykają się z kilkoma problemami. Przede wszystkim są to braki kadrowe. Większość pracy spada na, i tak nielicznych, nauczycieli chińskich, którzy muszą przetłumaczyć wszystkie treści dodatkowe podręcznika zaplanowane w języku chińskim, a do tego zająć się całym procesem wydawniczym na miejscu. Lektorzy z Polski natomiast mają mało czasu, ponieważ prowadzą wiele zajęć; ponadto nie wszyscy są przygotowani do pracy nad stworzeniem podręcznika i nie mają odpowiednich do niej narzędzi. Do głównych zadań autorów podręcznika do nauki polskiego należy też sprofilowanie odbiorcy i poznanie jego potrzeb edukacyjnych. Jak wspomniałam, stanowisk lektorskich nie obejmują na razie polscy sinolodzy, a jeśli nawet w najbliższej przyszłości będą je obejmować, niekoniecznie muszą dysponować odpowiednio szeroką wiedzą z zakresu glottodydaktyki polonistycznej, by stworzyć podręcznik do języka polskiego. Ciężar odpowiedzialności za przygotowanie podręcznika do nauki języka i kultury polskiej spada więc na chińskiego nauczyciela polonistę, który korzysta z własnych doświadczeń i intuicji.

\section{Podsumowanie}

Obecnej sytuacji glottodydaktyki polonistycznej na Dalekim Wschodzie nie da się porównać z żadną inną w historii tej dziedziny. Studia polskie w Azji przez kilkadziesiąt lat miały charakter niszowy i elitarny. Nadal taka jest ich specyfika w Republice Korei i Japonii, to jednak, co dzieje się z polonistyką w Chinach, niewątpliwie nie pozostanie bez echa. Już w tej chwili organizatorzy Spotkań Polonistyk Trzech Krajów w toku przygotowywania konferencji starają się troszczyć o zachowanie proporcji między reprezentantami Chin, Korei i Japonii (co może oznaczać, że w pewien sposób odczuwana jest przewaga Chin w tym zakresie). Pojawiają się też pytania, jak długo taka 
sytuacja polonistyk w Chinach będzie się utrzymywać, czy, a jeśli tak, to kiedy nastąpi nasycenie rynku polonistami. Kształceniu kompetentnych tłumaczy biznesowych przyświeca inicjatywa Jeden Pas, Jeden Szlak, rozwój gospodarczy, wymiana handlowa - które też są w jakimś stopniu ograniczone. Nie do przewidzenia są także skutki pandemii. Mało prawdopodobne wydaje się, żeby sytuacja chińskiej polonistyki wróciła do stanu sprzed 2009 roku, ale to, czy utrzyma się dwadzieścia polonistyk, nie jest przesądzone. To wszystko dywagacje. W tej chwili należy się skupić na stanie faktycznym chińskiej polonisty$\mathrm{ki}$ - na jej wyzwaniach, problemach i ich rozwiązaniach.

Najistotniejszym zadaniem wydaje się integracja polonistów w Chinach zarówno rodowitych Chińczyków, jak i lektorów z zagranicy - zapewnienie młodym nauczycielom możliwości dokształcania i wsparcia instytucji państwowych. Na wielu chińskich uczelniach studia polskie i lektoraty języka polskiego zostały utworzone na podstawie umów z uniwersytetami w Polsce, bez pośrednictwa NAWA. Trudno jednak o kompletne dane o stanie chińskiej polonistyki, ponieważ nie wszyscy dzielą się chętnie informacjami, co można zrozumieć, gdy się weźmie pod uwagę ogromną konkurencję między polonistykami w tym kraju. Ponad połowa ośrodków z listy dwudziestu, w których oferowane są studia polonistyczne lub lektoraty, nie ma jeszcze absolwentów, a jedna trzecia właściwie dopiero rozpoczęła działalność, w dodatku w czasach pandemii, co wiązało się z wieloma ograniczeniami. Na efekty kształcenia polonistycznego w Chinach, dane liczbowe i pełniejsze raporty trzeba będzie więc jeszcze poczekać.

Kolejnym wyzwaniem chińskiej polonistyki jest stworzenie programów nauczania, a także opracowanie adresowanych do chińskich studentów podręczników i pomocy dydaktycznych, zarówno podręczników kursowych, w których muszą być uwzględnione różnice systemowe oraz chińska tradycja metodyki nauczania, jak i materiałów do nauczania literatury, historii i kultury polskiej. Nie można też przejść obojętnie obok wyzwań rynku, na którym obserwuje się zainteresowanie stworzeniem podręczników przygotowujących do uczestniczenia w polsko-chińskim biznesie, handlu, ekonomii czy prawie.

Niewątpliwie jesteśmy świadkami i uczestnikami niemającego precedensu procesu powstawania i rozwoju studiów polskich poza granicami naszego kraju, w państwie tak odległym geograficznie, językowo i kulturowo jak Chiny. Należy czujnie obserwować i skrupulatnie opisywać ten proces — i czekać na efekty polityki językowej prowadzonej przez Państwo Środka. 


\section{Bibliografia}

II Ogólnochińskie Warsztaty Glottodydaktyczne. Pekin, 7-9 kwietnia 2019 r. [Materiały powarsztatowe]. Ambasada RP w Pekinie, Pekin 2019.

Gębal P.E., Miodunka W.T.: Dydaktyka i metodyka nauczania języka polskiego jako obcego i drugiego. PWN, Warszawa 2020. [e-book, format epub].

Li Yinan: Dydaktyka polonistyczna wobec inicjatywy ,Jeden pas, jeden szlak”: programy i metody. „Spotkania Polonistyk Trzech Krajów — Chiny, Korea, Japonia” 2016/2017, s. 387-398.

Li Yinan: Literatura polska w Chinach. Przedmowa Yi Lijun. Posłowie Zhao Gang. Uniwersytet Śląski-Wydawnictwo Gnome, Katowice 2017.

Li Yinan: Recepcja literatury polskiej w Chinach. Wybrane zagadnienia. Praca doktorska. Uniwersytet Śląski w Katowicach. 2015. Pobrano z: https://rebus.us.edu.pl/bitstream/20.500.12128/5731/1/ Li_Recepcja_literatury_polskiej_w_Chinach.pdf [2.09.2021].

Madelska L., Warchoł-Schlottmann M.: Odkrywamy język polski. Gramatyka dla uczacych (się) języka polskiego jako obcego. Wyd. 2. [Hura!!!]. Prolog Publishing, Kraków 2018.

Malejka J.: Na głęboka wodę, czyli o zaletach (i wadach) komunikowania się z Chińczykami wyłącznie po polsku. „Spotkania Polonistyk Trzech Krajów — Chiny, Korea, Japonia” 2009, s. 167177.

Malejka J.: Podejście międzykulturowe w nauczaniu języka polskiego w Chinach [w druku].

Malejka J.: Wykorzystanie podejścia międzykulturowego w nauczaniu języka polskiego $w$ Chinach na przykładzie kuchni. „Postscriptum Polonistyczne” 2020, nr 26 (2), s. 77—90. https://doi. org/10.31261/PS P.2020.26.06.

Małolepsza M., Szymkiewicz A.: Po polsku 1. Podręcznik studenta. Wyd. 2. popr. [Hura!!!]. Prolog Szkoła Języków Obcych, Kraków 2006.

Mao Rui: Chińscy studenci o rocznych stażach językowych w Polsce. „Kwartalnik Polonicum” 2018, nr 30, s. $57-66$.

Mazur J.: Lektor języka polskiego w zagranicznym ośrodku akademickim. Oczekiwania i rzeczywistość. W: W kręgu (glotto)dydaktyki. Red. A. Achtelik, K. Graboń. [Polonistyka na początku XXI wieku. Diagnozy, koncepcje, perspektywy. Red. J. Tambor. T. 5]. Wydawnictwo Uniwersytetu Śląskiego, Katowice 2018, s. 55-62.

Miodunka W., Wróbel J.: Polska po polsku. Podręcznik języka polskiego dla początkujących. T. 1. Interpress, Warszawa 1986.

Miodunka W.T. et al.: Nauczanie i promocja języka polskiego w świecie. Diagnoza, stan, perspektywy. Wydawnictwo Uniwersytetu Śląskiego, Katowice 2018.

Ruszer A.: Ogólnochińskie Warsztaty Glottodydaktyczne w Pekinie i promocja języka polskiego $w$ Chinach. [W przygotowaniu].

Stempek I., Stelmach A.: Polski krok po kroku. Seria podręczników do nauki języka polskiego dla obcokrajowców. Poziom A2. Polish-courses.com, Kraków 2012.

Tambor J.: Egzotyzmy kulinarne w i na języku Polaków. Rozważania o jedzeniu, mówieniu i pisaniu. „Spotkania Polonistyk Trzech Krajów — Chiny, Korea, Japonia” 2014/2015, s. 83-92.

Zhao Gang: 60 lat pekińskiej polonistyki. „Azja-Pacyfik” 2014, T. 17, s. 103-113. https://doi. org/10.15804/ap201405.

Żydek-Bednarczuk U.: Spotkanie kultur. Komunikacja i edukacja międzykulturowa w glottodydaktyce. Wydawnictwo Uniwersytetu Śląskiego, Katowice 2015. 